\begin{abstract}
Iranica
Abstracta Iranica Revue bibliographique pour le domaine irano-aryen

Volume 37-38-39 | 2018

Comptes rendus des publications de 2014-2016
\end{abstract}

\title{
Karen Radner (ed.). State Correspondence in the Ancient World, From New Kingdom Egypt to the Roman Empire
}

\section{Astrid Nunn}

\section{(2) OpenEdition Journals}

Édition électronique

URL : http://journals.openedition.org/abstractairanica/44063

DOI : 10.4000/abstractairanica.44063

ISBN : 1961-960X

ISSN : 1961-960X

Éditeur :

CNRS (UMR 7528 Mondes iraniens et indiens), Éditions de l'IFRI

\section{Référence électronique}

Astrid Nunn, « Karen Radner (ed.). State Correspondence in the Ancient World, From New Kingdom Egypt to the Roman Empire », Abstracta Iranica [En ligne], Volume 37-38-39 | 2018, document 1, mis en ligne le 30 décembre 2018, consulté le 27 septembre 2020. URL : http://journals.openedition.org/ abstractairanica/44063 ; DOI : https://doi.org/10.4000/abstractairanica.44063

Ce document a été généré automatiquement le 27 septembre 2020

Tous droits réservés 


\title{
Karen Radner (ed.). State Correspondence in the Ancient World, From New Kingdom Egypt to the Roman Empire
}

\author{
Astrid Nunn
}

\section{RÉFÉRENCE}

Karen Radner (ed.). State Correspondence in the Ancient World, From New Kingdom Egypt to the Roman Empire. Oxford, New York: Oxford University Press, 2014, xiv+306 p. (Oxford Studies in Early Empires).

1 La toile de fonds thématique est la communication à longue distance entre empires. L'éditrice considère cette forme de communication comme un élément stabilisateur et se demande dans quelle stratégie et quel réseau les empires ont-ils investi pour la développer et en profiter. L'assyriologue K. Radner a invité des spécialistes de l'Egypte d'Amarna, du royaume hittite, de la Babylonie, de la Perse achéménide ainsi que du monde hellénistique et romain à se pencher sur certaines questions communes à toutes les contributions: quel est le rôle des messagers, des lettres et des scribes dans la communication à longue distance? Quelle était la langue utilisée pour la correspondance d'Etat? Existe-t-il un système privilégié pour la communication entre états et comment l'information était-t-elle sécurisée pendant le transfert ? Existe-t-il des modèles ou des règles de communication? Les lettres archivées sont-elles rendues publiques et ont-elles servi de référence pour le futur? Le chapitre 5 a été écrit par Amélie Kuhrt « State Communications in the Persian Empire » (renvoi au cr). 


\section{AUTEURS}

\section{ASTRID NUNN}

Université de Munich 